Acta Protozool. (2017) 56: 93-107

www.ejournals.eu/Acta-Protozoologica

doi:10.4467/16890027AP.17.008.7483

PROTOZOOLOGICA

\title{
Taxonomic and Morphogenetic Description of the Freshwater Ciliate Aponotohymena isoaustralis n. sp. (Ciliophora; Oxytrichidae) Isolated from Sanjay Lake, Delhi, India
}

\author{
Renu GUPTA ${ }^{1}$, Jeeva Susan ABRAHAM ${ }^{2}$, Sripoorna SOMASUNDARAM ${ }^{2}$, Ravi TOTEJA ${ }^{2}$, Seema \\ MAKHIJA ${ }^{2}$ and Hamed A EL-SEREHY ${ }^{3}$
}

${ }^{1}$ Maitreyi College, University of Delhi, Bapudham Complex, Chanakyapuri, New Delhi, India; ${ }^{2}$ Ciliate Biology Laboratory, Acharya Narendra Dev College, University of Delhi, Govindpuri, Kalkaji, New Delhi, India; ${ }^{3}$ Zoology Department, College of Science, King Saud University, Riyadh Saudi Arabia

\begin{abstract}
Morphology, morphogenesis and molecular phylogeny of a freshwater oxytrichid ciliate, Aponotohymena isoaustralis n. sp. collected from Sanjay Lake $\left(28^{\circ} 36^{\prime} 51^{\prime \prime} \mathrm{N}, 77^{\circ} 18^{\prime} 14^{\prime \prime} \mathrm{E}\right)$, Delhi, India, were studied. The described species is characterized by a flexible body, with body size (in vivo) of about $148 \times 46 \mu \mathrm{m}$ and yellowish green cortical granules. Morphological characters exhibit: undulating membranes in Notohymena-pattern; two macronuclei and absence of micronucleus (amicronucleate); about 36 adoral membranelles; 18 frontoventral-transverse (FVT) cirri; one right and one left marginal row separated posteriorly; 6 dorsal rows; 7 caudal cirri arranged in $2+2+3$ pattern (constant). In the present study, a detailed description of all the developmental stages is also provided. Prominent distinguishing features of the new species are the absence of micronucleus, 7 caudal cirri (constant), yellowish green cortical granules aligned along the margins and irregularly distributed throughout the cell. They may also be randomly concentrated as clusters along the left margin and posterior end of the cell. Molecular phylogeny based on small subunit rDNA sequence data suggests sister relationship of Aponotohymena isoaustralis $\mathrm{n}$. $\mathrm{sp}$. with Notohymena apoaustralis and Aponotohymena australis (Notohymena australis) which cluster in a clade with Paraurostyla weissei and Paraurostyla coronata. Further analysis of nucleotide sequence of SSU rDNA also suggests that $A$. isoaustralis n. sp. is distinct from the type species $A$. australis.
\end{abstract}

Key words: Aponotohymena, morphogenesis, morphology, oxytrichid, phylogeny, SSU rDNA

\section{INTRODUCTION}

The genus Notohymena was established by Blatterer and Foissner (1988) distinguishing it from the genus

Address for correspondence: Seema Makhija, Ciliate Biology Laboratory, Department of Zoology, Acharya Narendra Dev College, University of Delhi, Govindpuri, Kalkaji, New Delhi, 110019, India. Tel. number: +91-011-26294542, Ext: 247; +919136563762; Fax:+91-011-26294540, e-mail: seemamakhija@andc.du.ac.in
Oxytricha as it has a distinct hook shaped distal end of paroral membrane (PM), recognizable only after protargol impregnation (Berger 1999). Since the establishment of the genus, nine species have been assigned to it: N. selvatica (Hemberger 1985, Blatterer and Foissner 1988), N. rubescens (Blatterer and Foissner 1988), N. australis (Foissner and O' Donoghue 1990, Berger 1999, Voss 2008, Hu and Kusuoka 2015), N. antarctica (Foissner 1996), N. pampasica (Küppers et al. 2007), N. saprai (Kamra and Kumar 2010), N. apoaustralis 
(Lv et al. 2013), N. quadrinucleata (Foissner 2016) and N. limus (Naqvi et al. 2016). Notohymena australis has been redesignated as Aponotohymena australis by Foissner (2016) on the basis of: flexible body; 18 FVT cirri; more than 3 caudal cirri associated with dorsal kineties 1, 2 and 4; splitting of $\mathrm{DP}_{3}$ (third dorsal primordium).

Present investigation describes the morphology, morphogenesis and phylogenetic relationship of a new freshwater species of Aponotohymena genus isolated from Sanjay Lake, Delhi, India. Morphological, morphometric and molecular analysis indicates that $A$. isoaustralis n. sp. is a new species. The systematic and phylogenetic position of this species within the family Oxytrichidae is also assessed by using SSU rDNA as molecular marker gene.

\section{MATERIALS AND METHODS}

\section{Sampling site and cultivation}

Water samples were collected in large beakers along with the root system of water hyacinth and mixed planktonic cultures from the sides of the lake on September 12, 2013 from Sanjay Lake, which is an artificial freshwater lake in Trilokpuri $\left(28^{\circ} 36^{\prime} 51^{\prime \prime} \mathrm{N}\right.$, $77^{\circ} 18^{\prime} 14^{\prime \prime} \mathrm{E}$ ), East Delhi, India. Its surface area is about one square kilometer and has an extensive growth of water hyacinth. It is mainly a rain water lake but occasionally receives inputs from sewage. Water temperature and $\mathrm{pH}$ at the time of collection were $22.5^{\circ} \mathrm{C}$ and 7.2 respectively. A clonal culture of Aponotohymena isoaustralis n. sp. was maintained in the laboratory at $22-23^{\circ} \mathrm{C}$ in Pringsheim's medium (Chapman-Andresen 1958). Boiled cabbage was added to the medium to promote the growth of bacteria which served as the primary food source.

\section{Morphology and morphogenesis}

In vivo observations were done using stereomicroscope, phase contrast microscope and differential interference contrast microscope. Protargol impregnation (Wilbert 1975, Kamra and Sapra 1990) was used to reveal the infraciliature. Nuclear morphology was observed from Feulgen stained cells (Chieco and Derenzini 1999). Counts and measurements of the impregnated specimens were performed at magnification of $1000 \times$. Terminology is mainly according to Berger (1999, 2008); Foissner and Stoeck (2011) and Küppers et al. (2011). Numbering system used is according to Borror (1972) and Wallengren (1900).

\section{DNA extraction, amplification and sequencing}

Cell culture $(50 \mathrm{ml})$ was taken and filtered using 120 micron Nytex mesh to remove cabbage from the medium. Cells were then centrifuged to obtain a cell pellet with minimal volume of medium and washed to remove any potential contamination. Genomic DNA was extracted as per protocol for cultured animal cells using DNeasy Blood and Tissue Kit (QIAGEN, India)
Primers for SSU rDNA gene amplification were 18S-F(5'-AAC CTG GTT GAT CCT GCC AGT-3') and 18S-R (5'-TGA TCC TTC TGC AGG TTC ACC TAC-3') (Lv et al. 2013, Medlin et al. 1988). Additionally, two internal primers: one forward (5'-CGGTAATTCCAGCTCCAATAG-3') and one reverse (5'-AACTAAGAACGGCCATGCAC-3') were used. PCR conditions were as follows: $1^{\text {st }}$ cycle with denaturation at $95^{\circ} \mathrm{C}$ for $5 \mathrm{~min}$, annealing at $48^{\circ} \mathrm{C}$ for $1 \mathrm{~min}$ and elongation at $72^{\circ} \mathrm{C}$ for $1 \mathrm{~min}$, followed by 30 cycles with denaturation at $95^{\circ} \mathrm{C}$, annealing at $48^{\circ} \mathrm{C}$ and elongation at $72^{\circ} \mathrm{C}$ for $45 \mathrm{~s}$ each and last cycle with denaturation at $95^{\circ} \mathrm{C}$ for $45 \mathrm{~s}$, annealing at $48^{\circ} \mathrm{C}$ for $45 \mathrm{~s}$ and elongation at $72^{\circ} \mathrm{C}$ for 10 min. PCR product was eluted using Q1Aquick Gel Extraction kit (QIAGEN, India). The eluted product was sequenced using Applied Biosystems 3130xl Automated DNA Sequencer.

\section{SSU rDNA analysis and phylogenetic tree construc- tion}

SSU rDNA sequence was submitted to BLAST search (http:// www.ncbi.nlm.nih.gov) to find closely related sequences. SSU rDNA sequences of a total of 39 other taxa were retrieved. Sequences were aligned using CLUSTAL X2 sequence analysis software (Larkin et al. 2007). The resulting alignments were checked and corrected manually to remove ambiguous nucleotide positions at the beginning and end of the fragments in the BioEdit editor (Hall 1999). Also, the SSU rDNA sequences of $N$. apoaustralis and A. australis were selected and separately aligned with $A$. isoaustralis n. sp. by using BioEdit software and were simultaneously analyzed to calculate the differences in nucleotide sequences. Phylogenetic tree using Maximum Likelihood method was constructed with the MEGA 5 (Molecular Evolutionary Genetics Analysis) software package (Tamura et al. 2011). Also, Bayesian Inference tree was constructed using MrBayes 3.2.4 program under GTR + I + G model where 1,00,000 Markov Chain Monte Carlo generations were sampled with a $25 \%$ burn-in for tree construction. 1000 bootstrap replicates were used to calculate supporting values. The final BI tree was viewed using TreeView software.

\section{RESULTS}

Morphology of Aponotohymena isoaustralis n. sp.

Live cell: Average body size in vivo $148 \times 46 \mu \mathrm{m}$ $(n=25)$, length: width ratio $4: 1$, elongated body; dorsoventrally flattened about $2: 1$, flexible, colourless cytoplasm with a greenish appearance at the margins when observed at low magnifications. Yellowish green cortical granules about $0.8 \mu \mathrm{m}$ in diameter aligned along the margins and irregularly distributed throughout the cell; they may also be randomly concentrated as clusters along the left margin and posterior end of the cell. Single contractile vacuole about $15 \mu \mathrm{m}$ in diameter located below the AZM near the left margin. Cell division every $11 \mathrm{~h}$. Encystment generally takes place within $24 \mathrm{~h}$ of starvation; the average diameter of the resting cyst in life is $64.53 \mu \mathrm{m}(\mathrm{n}=12)$ with smooth ectocyst covered 

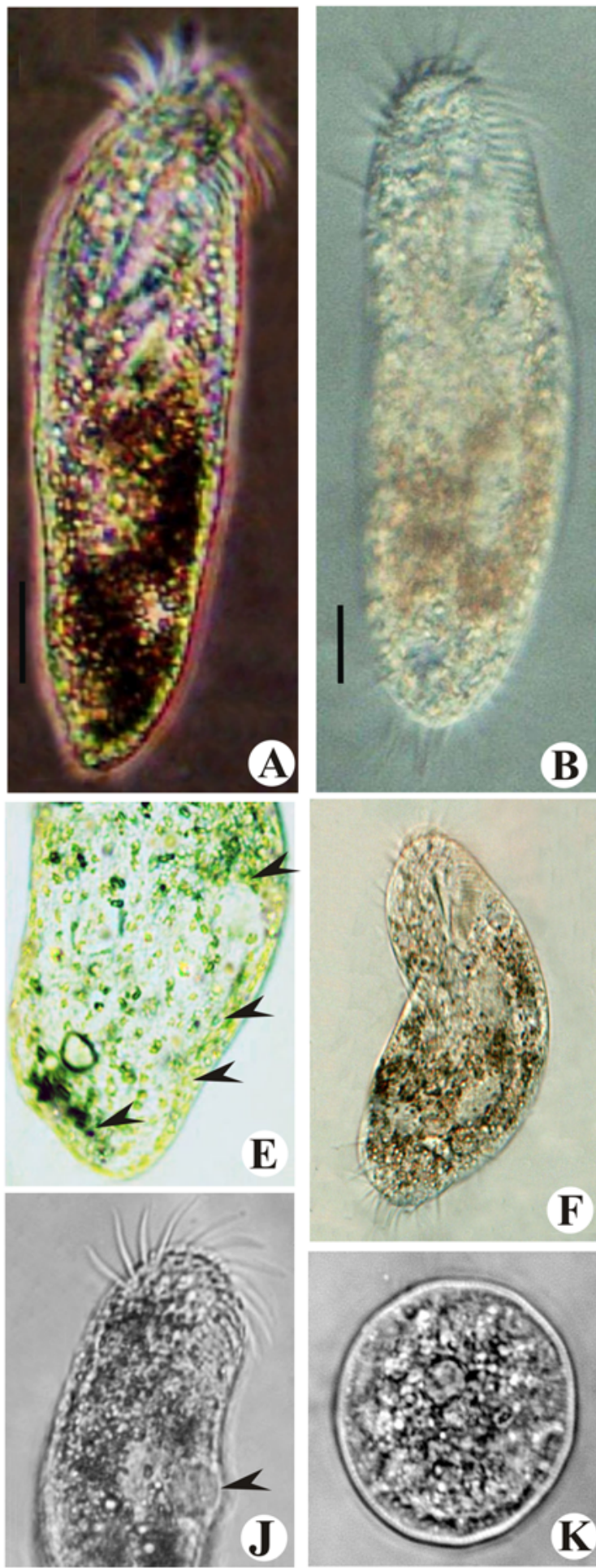
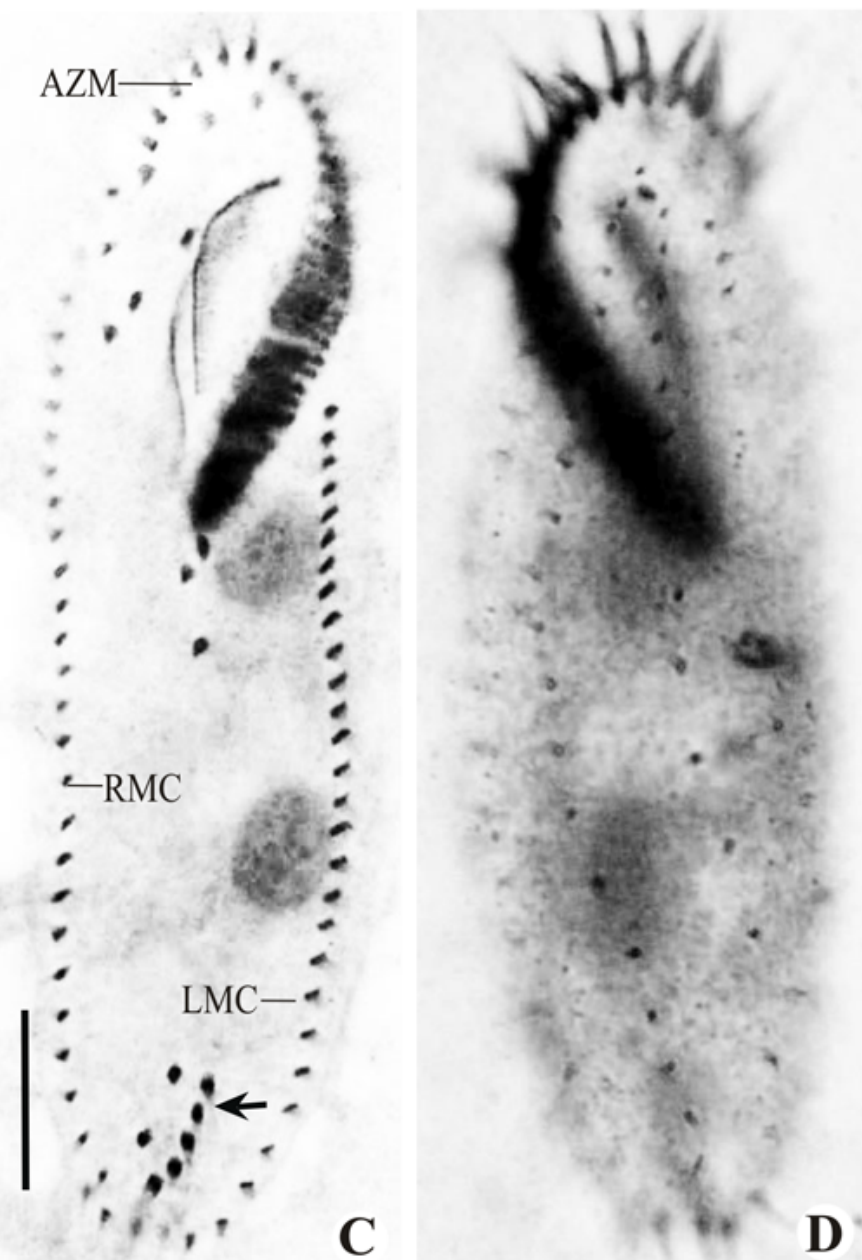

C

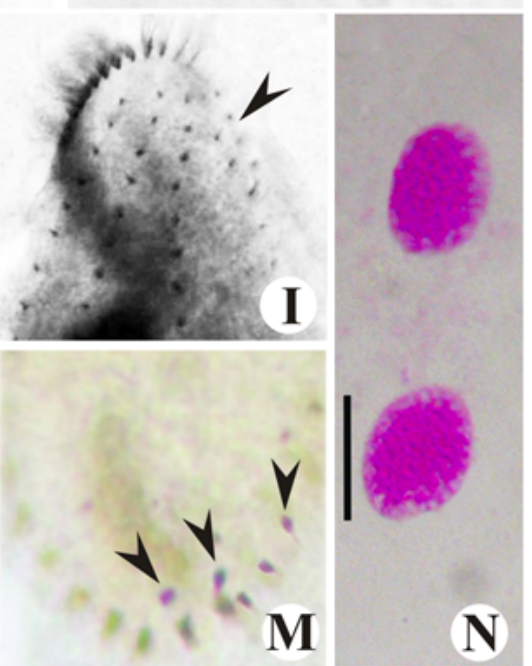

Fig. 1. Photomicrographs of live (A, B, E, F, G, H, J, K), protargol impregnated (C, D, I, L, M) and Feulgen stained (N) cells of Aponotohymena isoaustralis $\mathrm{n}$. sp. A, B - cells in ventral view; $\mathbf{C}$ - ventral view of a vegetative cell with 5 transverse cirri arranged in a pseudo row (arrow); D - dorsal view of a vegetative cell; $\mathbf{E}$ - ventral view to show the arrangement of cortical granules (arrowheads) and colouration; F, G and $\mathbf{H}$ - ventral view of different cells showing flexible body; I - anterior portion of the dorsal surface showing dorsal rows (arrowhead); $\mathbf{J}$ - anterior portion of the cell showing contractile vacuole (arrowhead); $\mathbf{K}$ - cyst; $\mathbf{L}$ - anterior hook (arrowhead) of paroral membrane; $\mathbf{M}$ - dorsal view showing caudal cirri $(2+2+3)$ (arrowheads); $\mathbf{N}$ - two macronuclei. AZM - adoral zone of membranelles, LMC - left marginal cirri, RMC - right marginal cirri. Scale bars: $20 \mu \mathrm{m}$. 
with mucus layer and granulated cytoplasm (Fig 1A, B, E-H, J, K).

Nuclear morphology: Two macronuclear nodules each about $20 \times 14 \mu \mathrm{m}$ in size (in protargol preparations), spherical to ellipsoidal, located along the cell mid line, one about $19 \mu \mathrm{m}$ away from the anteriormost part and the other about $16 \mu \mathrm{m}$ away from the posteriormost part of the cell; distance between the two macronuclei is about $22.2 \mu \mathrm{m}$; micronucleus absent (Fig. $1 \mathrm{~N}$ ).

Infraciliature characteristics: Adoral zone of membranelles (AZM) occupies about $34 \%$ of the body length in protargol preparations and is composed of 3240 membranelles. Undulating membrane (UM) with a characteristic hook at the distal end (Notohymenapattern); 18 FVT cirri with 3 frontal cirri, 4 frontoventral cirri, 1 buccal cirrus, 3 postoral ventral cirri, 2 pretransverse ventral cirri and 5 transverse cirri; transverse cirri equidistant to each other and usually arranged in a pseudo row. IV/2 and V/4 are closely placed whereas $\mathrm{V} / 3$ is distantly placed (distance between $\mathrm{IV} / 2$ and $\mathrm{V} / 4$ is $3.10 \mu \mathrm{m}$ and between $\mathrm{V} / 4$ and $\mathrm{V} / 3$ is $5.14 \mu \mathrm{m})$. Marginal rows are separated (nonconfluent) posteriorly

Table 1. Morphometric characterization of protargol impregnated cells of Aponotohymena isoaustralis $\mathrm{n}$. $\mathrm{sp}$.

\begin{tabular}{|c|c|c|c|c|c|c|c|}
\hline Character* & Mean & Min & Max & Median & SD & SE & $\mathrm{CV}$ \\
\hline Body, length & 132.3 & 115.5 & 161.2 & 129.4 & 12 & 2.4 & 9 \\
\hline Body, width & 34.8 & 26.7 & 52.8 & 33.60 & 6.0 & 1.2 & 17.3 \\
\hline Adoral zone of membranelles, length & 44.6 & 33.8 & 52.3 & 44.2 & 4.1 & 0.8 & 9.1 \\
\hline Adoral membranelles, number & 36.4 & 32 & 40 & 36 & 2.1 & 0.4 & 5.7 \\
\hline Frontal cirri, number & 3 & 3 & 3 & 3 & 0 & 0 & 0 \\
\hline Frontoventral cirri, number & 4 & 4 & 4 & 4 & 0 & 0 & 0 \\
\hline Buccal cirri, number & 1 & 1 & 1 & 1 & 0 & 0 & 0 \\
\hline Postoral ventral cirri, number & 3 & 3 & 3 & 3 & 0 & 0 & 0 \\
\hline Pretransverse ventral cirri, number & 2 & 2 & 2 & 2 & 0 & 0 & 0 \\
\hline Transverse cirri, number & 5 & 5 & 5 & 5 & 0 & 0 & 0 \\
\hline Caudal cirri, number & 7 & 7 & 7 & 7 & 0 & 0 & 0 \\
\hline Left marginal cirri, number & 34.4 & 30 & 38 & 35 & 1.9 & 0.4 & 5.6 \\
\hline Right marginal cirri, number & 32.9 & 30 & 38 & 32 & 2.1 & 0.4 & 6.4 \\
\hline Dorsal kineties, number & 6 & 6 & 6 & 6 & 0 & 0 & 0 \\
\hline $\mathrm{DK}_{1}$, dikinetids number & 20.4 & 18 & 22 & 21 & 1.8 & 0.4 & 8.8 \\
\hline $\mathrm{DK}_{2}$, dikinetids number & 20.4 & 18 & 22 & 21 & 1.8 & 0.4 & 8.7 \\
\hline $\mathrm{DK}_{3}$, dikinetids number & 16.9 & 16 & 18 & 17 & 0.9 & 0.2 & 5.5 \\
\hline $\mathrm{DK}_{4}$, dikinetids number & 8 & 8 & 8 & 8 & 0 & 0 & 0 \\
\hline $\mathrm{DM}_{1}$, dikinetids number & 8 & 8 & 8 & 8 & 0 & 0 & 0 \\
\hline $\mathrm{DM}_{2}$, dikinetids number & 6 & 6 & 6 & 6 & 0 & 0 & 0 \\
\hline Macronuclei, number & 2 & 2 & 2 & 2 & 0 & 0 & 0 \\
\hline Micronucleus, number & 0 & 0 & 0 & 0 & 0 & 0 & 0 \\
\hline Anterior macronucleus, length & 20.8 & 16.1 & 38.4 & 19.5 & 5.1 & 1.0 & 24.5 \\
\hline Anterior macronucleus, width & 14.3 & 10.1 & 17.5 & 14.6 & 2.1 & 0.4 & 14.8 \\
\hline Posterior macronucleus, length & 19.4 & 13.8 & 26.4 & 19.5 & 2.6 & 0.5 & 13.4 \\
\hline Posterior macronucleus, width & 13.6 & 7.6 & 18 & 13.9 & 2.4 & 0.5 & 17.4 \\
\hline Distance between the two macronuclei & 22.2 & 9.3 & 41.6 & 18.8 & 9.0 & 1.8 & 40.8 \\
\hline $\mathrm{CC}$ in kinety 1, number & 2 & 2 & 2 & 2 & 0 & 0 & 0 \\
\hline $\mathrm{CC}$ in kinety 2, number & 2 & 2 & 2 & 2 & 0 & 0 & 0 \\
\hline $\mathrm{CC}$ in kinety 4 , number & 3 & 3 & 3 & 3 & 0 & 0 & 0 \\
\hline
\end{tabular}

*All measurements are in $\mu \mathrm{m}(\mathrm{n}$ - sample size - 25). CC - caudal cirri; CV - coefficient of variation (\%); DK - dorsal kineties; DM - dorsomarginal; Max - maximum; Min - minimum; SD - standard deviation; SE - standard error. 
with about $30-38$ cirri in right and left marginal row (Figs 1C, L, 2A; Table 1).

The dorsal ciliature is of typical oxytrichid pattern with 4 dorsal kineties $\left(\mathrm{DK}_{1-4}\right)$ and 2 dorsomarginal rows $\left(\mathrm{DM}_{1,2}\right)$. Three dorsal kineties $\left(\mathrm{DK}_{1-3}\right)$ encompass the entire length of the cell whereas $\mathrm{DK}_{4}$ commences near midline of the cell and extends to posterior end. DM and $\mathrm{DM}_{2}$ start at the anterior end of the cell and terminate at $1 / 3^{\text {rd }}$ of the cell length. Length of the dorsal bristles varies from 0.7 to $2.15 \mu \mathrm{m}$ (average bristle length in $\mathrm{DK}_{1}=2.15 \mu \mathrm{m}, \mathrm{DK}_{2}=1.82 \mu \mathrm{m}, \mathrm{DK}_{3}=1.04 \mu \mathrm{m}, \mathrm{DK}_{4}$

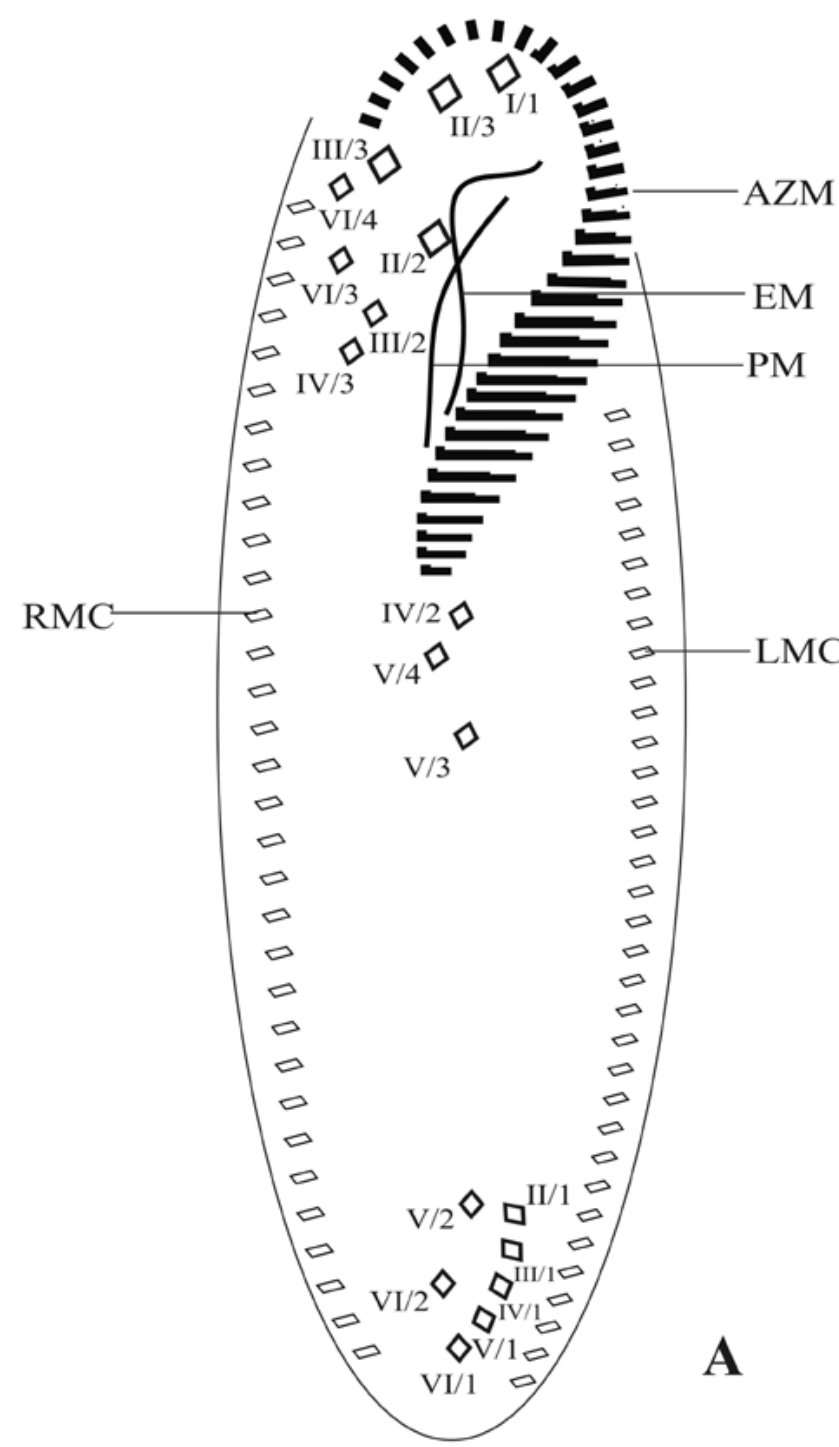

$=1.65 \mu \mathrm{m}, \mathrm{DM}_{1}=1.74 \mu \mathrm{m}$ and $\mathrm{DM}_{2}=0.7 \mu \mathrm{m} ; \mathrm{n}=10$ cells). Seven caudal cirri (CC) are arranged in $2+2+3$ pattern at the end of $\mathrm{DK}_{1,2 \& 4}$ respectively; caudal cirri are about $6.25 \mu \mathrm{m}$ long (Figs 1D, I, M, 2B; Table 1).

\section{Morphogenesis}

Stomatogenesis: The first morphogenetic event is the occurrence of a group of scattered basal bodies for oral primordium (OP) which arises apokinetally on the ventral surface between the postoral ventral cirri (POVC) and the left marginal row. There is no contri-

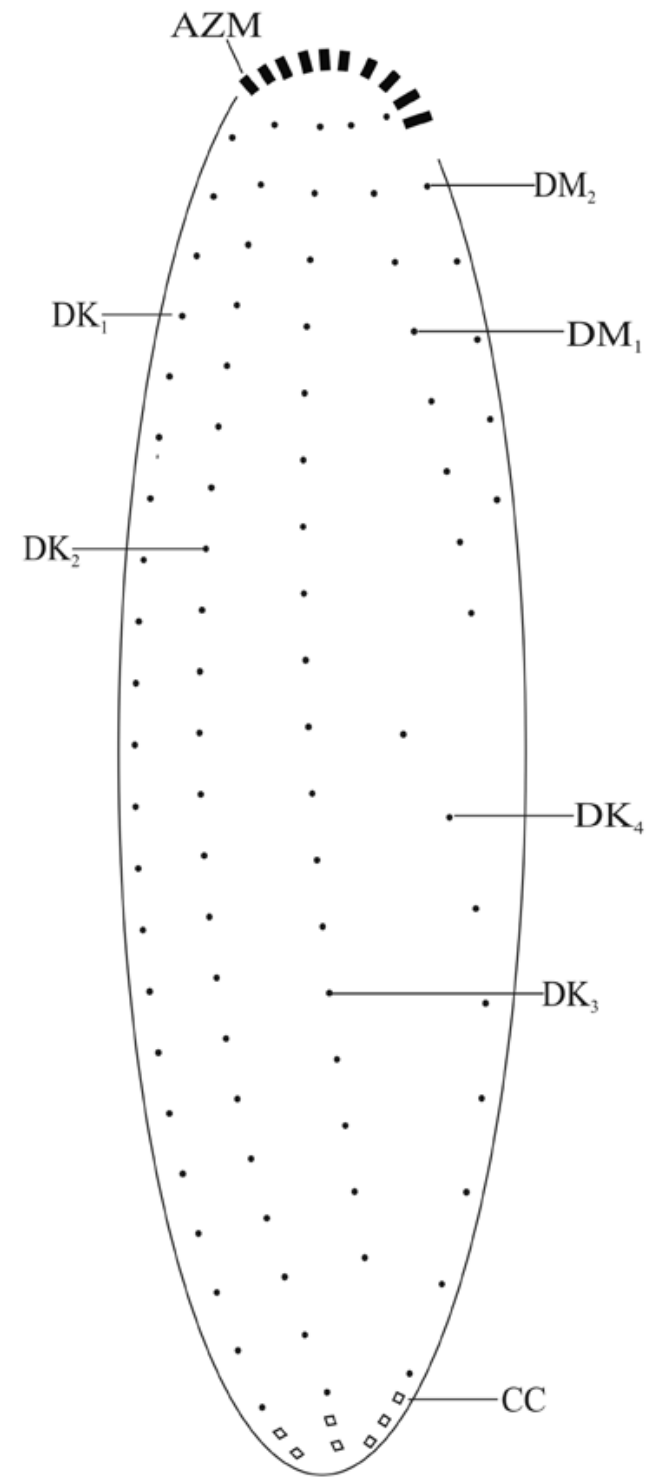

Fig. 2. Line diagrams showing protargol impregnated vegetative cells of Aponotohymena isoaustralis $\mathrm{n}$. sp. A-ventral surface; B - dorsal surface. AZM - adoral zone of membranelles, CC - caudal cirri, $\mathrm{DK}_{1-4}$ - dorsal kineties, $\mathrm{DM}_{1,2}$ - dorsomarginals, EM - endoral membrane, LMC - left marginal cirri, PM - paroral membrane, RMC - right marginal cirri, II/2 - buccal cirri, I/1, II/3, III/3 - frontal cirri, VI/4, VI/3, IV/3, III/2 - frontoventral cirri, - IV/2, V/4, V/3 - postoral ventral cirri, V/2 and VI/2 - pretransverse ventral cirri, II/1, III/1, IV/1, V/1, $\mathrm{VI} / 1$ - transverse cirri. Scale bar: $20 \mu \mathrm{m}$. 

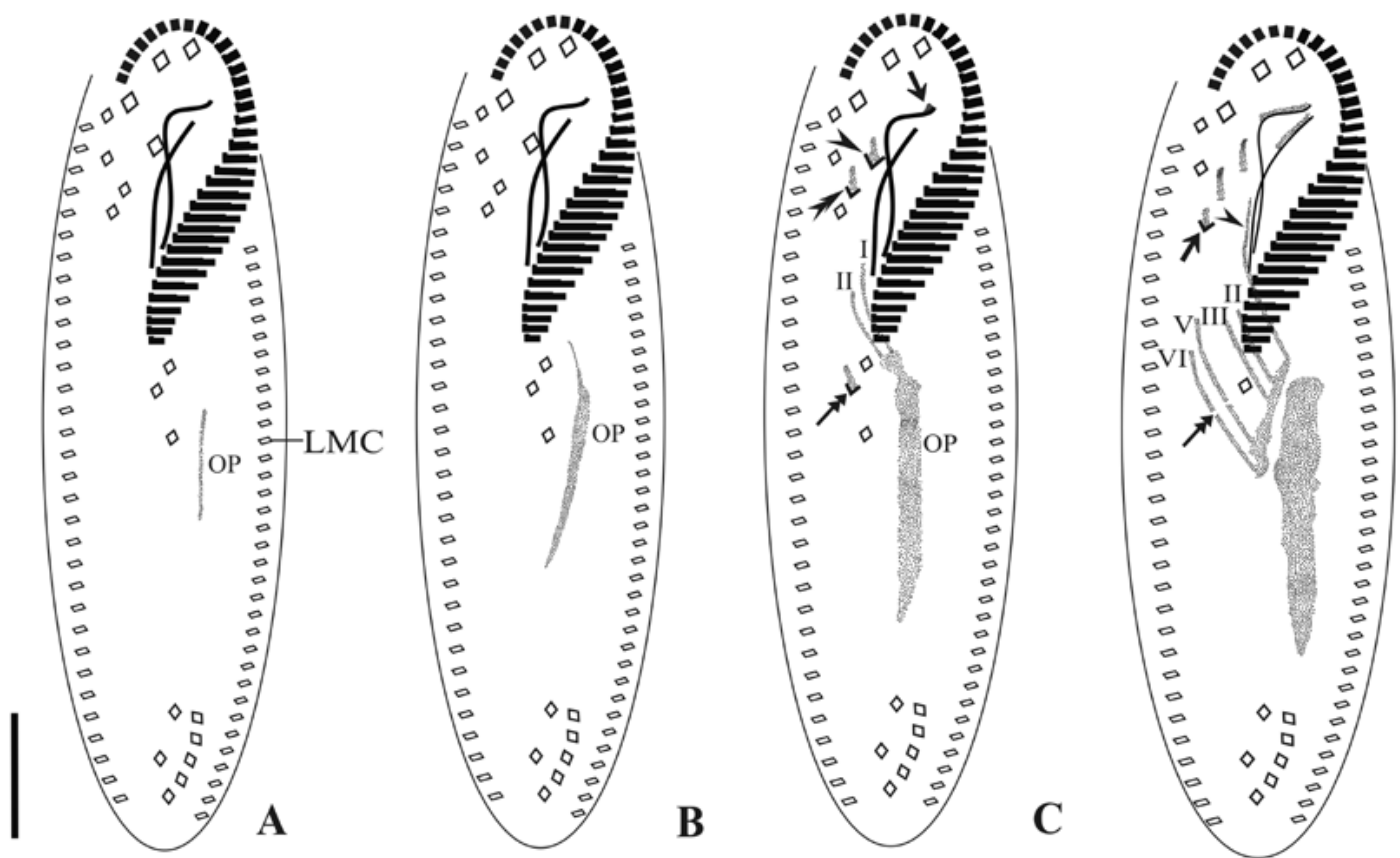

D
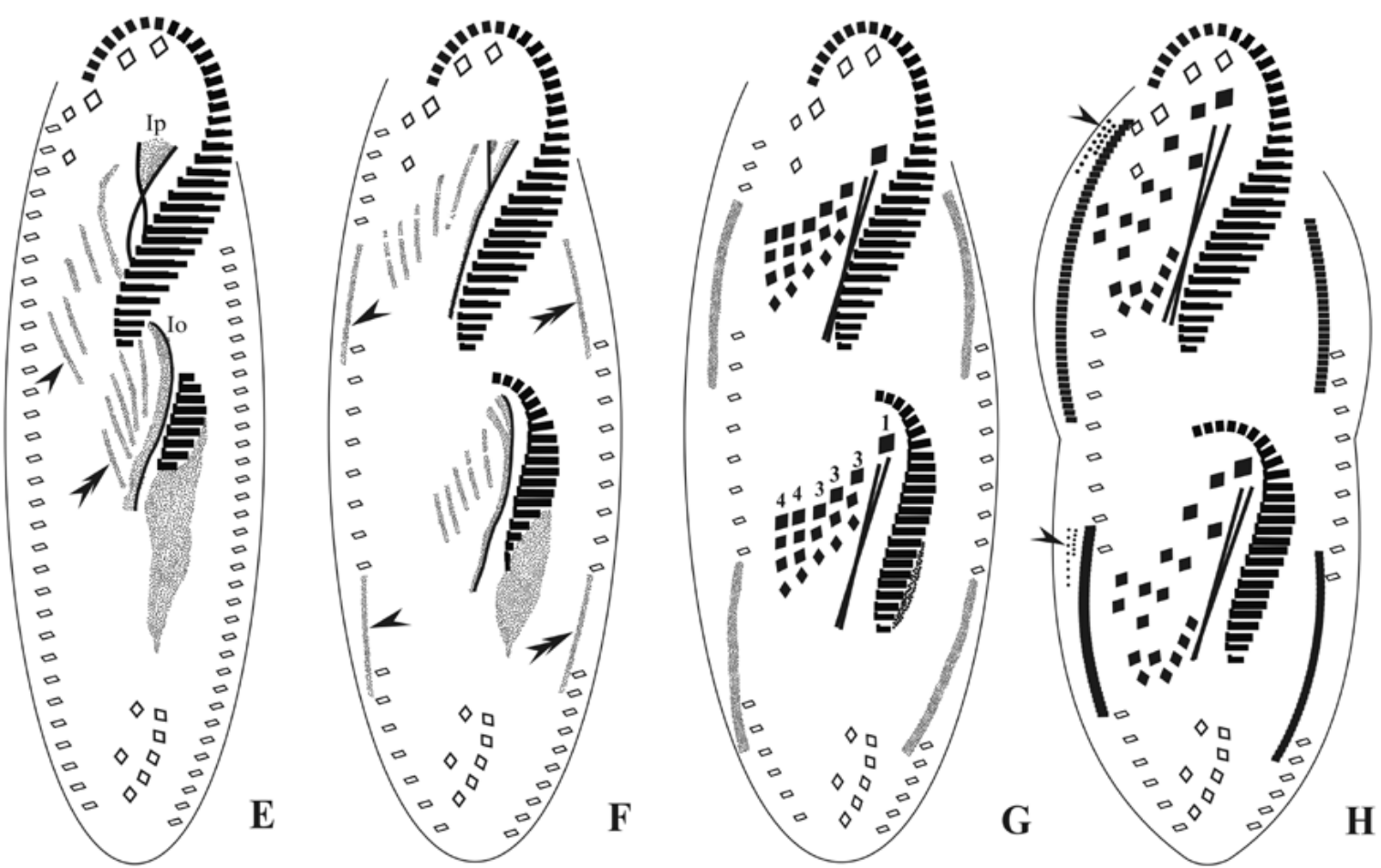

Fig. 3. Line diagrams showing morphogenetic stages on ventral surface of protargol impregnated cells of Aponotohymena isoaustralis n. sp. A, B - origin of OP apokinetally between the LMC and POVC for the opisthe; $\mathbf{C}$ - reorganization of parental UM (arrow), disaggregation of II/2 (arrowhead), III/2 (double arrowhead) and V/4 (double arrow) to form primordia IIp, IIIp and Vo respectively, kinetosomes from OP form primordia Io and IIo; D - dissagregation of IV/3 to form primordium IVp (arrow); kinetosomes from OP move anteriorly (arrowhead); the two primary primordia, one each formed from disaggregation of $\mathrm{V} / 4$ and $\mathrm{V} / 3$ split transversely (double arrow) to form primordia $\mathrm{V}$ and VI for proter and opisthe; $\mathbf{E}$ - full complement of 6 FVT primordia Ip to VIp (arrowhead) and Io to VIo (double arrowhead); $\mathbf{F}$ - within-row marginal primordia formation for RMC (arrowheads) and LMC (double arrowheads); $\mathbf{G}$ - differentiation of cirri in 1, 3, 3, 3, 4, 4 pattern; $\mathbf{H}$ - late divider showing formation of new dorsomarginals (arrowheads) close to newly formed RMC. LMC - left marginal cirri; OP - oral primordium. Scale bar: $20 \mu \mathrm{m}$. 
bution of the transverse cirri and POVC in the formation of the OP, indicating de novo origin of OP (Figs $3 \mathrm{~A}, \mathrm{~B}, 4 \mathrm{~A}, \mathrm{~B})$. The primordium then elongates, widens and the adoral membranelles begin to organize end forming new AZM for the opisthe. The parental AZM is retained intact during the morphogenetic process for the proter.

\section{Development of the cirral primordia:}

Opisthe. Streaks I-III arise from the developing oral primordium (OP). The ventral cirri IV/2, V/4 and $\mathrm{V} / 3$ disaggregate independently giving rise to streaks IVo, Vo and VIo respectively. Cirrus V/4 disaggregates first giving rise to the streak Vo followed by $V / 3$ to form streak VIo and lastly IV/2 disaggregates to form the streak IVo. Simultaneously, the two undulating membranes are formed from Io (Figs 3C, D, 4C, D).

Proter. The anterior portion of the parental paroral membrane (PM) reorganizes partially to form the streak Ip. The buccal cirrus (II/2) and the frontoventral cirri (III/2 and IV/3) form the streaks IIp, IIIp and IVp respectively. Kinetosomes from OP move anteriad and also contribute in the formation of IIp (Figs 3C, 4D, E). Streak Vo and VIo extend anteriorly and split transversely (splitting of primary primordia) giving rise to streaks Vp and VIp for the proter. Thus, 6 parental cirri (II/2, III/2, IV/3, IV/2, V/4 and V/3) are involved in primordia formation (Figs $3 \mathrm{C}-\mathrm{E}, 4 \mathrm{C}-\mathrm{E}$ ).

The two sets of 18 FVT cirri arise in typical oxytrichid pattern of 1, 3, 3, 3, 4, 4 (Figs 3G, H, 4I-K).

Development of marginal rows: The streaks for the new marginal cirri are formed within the parental marginal rows. The marginal primordia elongate with disaggregation of 10-12 parental cirri which differentiate into new marginal rows replacing the old ones. Rest of the parental marginal cirri are resorbed in later stages of development (Figs 3F-H, 4I, J).

Development of dorsal ciliature: The dorsal ciliature is formed as in most other oxytrichids. Three dorsal primordia $\mathrm{DP}_{1-3}$ are formed at two levels within the parental $\mathrm{DK}_{1-3}$. $\mathrm{DP}_{4}$ is formed by an unequal fragmentation of $\mathrm{DP}_{3}$. The two dorsomarginals originate on the ventral surface, close to the anterior end of the right marginal primordia (Figs 3H, 4J). Caudal cirri differentiate in the $2+2+3$ pattern at the posterior ends of the new dorsal kineties $\mathrm{DK}_{1,2 \& 4}$ (Fig. 5).

As cytokinesis commences, the new cirri arrange themselves according to their species-specific pattern while the remaining parental ciliature undergoes resorption.

\section{Molecular analysis}

The length of the SSU rDNA sequence of $A$. isoaustralis $\mathrm{n}$. sp. was $1,703 \mathrm{bp}$ and GC content was $44.74 \%$ and the sequence is available in GenBank with accession number KP336402. The percentage differences in nucleotide sequence of SSU rDNA between $A$. isoaustralis n. sp. and A. australis is $2.92 \%$ and between A. isoaustralis $\mathrm{n}$. sp. and N. apoaustralis is $4.24 \%$.

\section{Phylogenetic analysis based on SSU rDNA sequence}

Phylogenetic analysis was done including 39 taxa from GenBank (26 Sporadotrichida, 6 Stichotrichida and 7 Urostylida) and $A$. isoaustralis n. sp. In the analysis, A. isoaustralis n. sp., $N$. apoaustralis and A. australis clustered together with high support $(98 \%$ ML and $100 \%$ BI value). This group formed a clade with Paraurostyla weissei and Paraurostyla coronata with a moderate support (63\% ML and 57\% BI value) (Fig. 6).

\section{DISCUSSION}

\section{Justification of new species Aponotohymena iso- australis n. sp.}

Aponotohymena isoaustralis $\mathrm{n}$. $\mathrm{sp}$. is distinct from A. australis and $N$. apoaustralis on the basis of morphology, morphometry and SSU rDNA gene (Table 2).

(1) Micronuclei: The most distinguishing feature is the absence of micronucleus in A. isoaustralis n. sp. whereas, in $A$. australis the number of micronuclei varies from 3-8 and in $N$. apoaustralis one micronucleus is reported. Existence of amicronucleate species of Stylonychia, Oxytricha, Paraurostyla and Tetrahymena have been reported earlier as well (Prescott 1994, Doerder 2014).

(2) Caudal cirri: The number of caudal cirri is 7 (constant) in A. isoaustralis $\mathrm{n}$. sp. whereas the number of caudal cirri varies from 5-10 (variable) in A. australis and 8-10 (variable) in N. apoaustalis (Table 2).

(3) Cortical granules: The colour of cortical granules is yellowish green in all the three species whereas the position of granules varies which may be one of the diagnostic features in species identification. In A. isoaustralis $\mathrm{n}$. $\mathrm{sp}$. granules are aligned along the margins and also irregularly distributed throughout the cell. They may also be randomly concentrated as clusters along the left margin and posterior end of the cell. In A. australis, granules group around cirri and dorsal cilia 

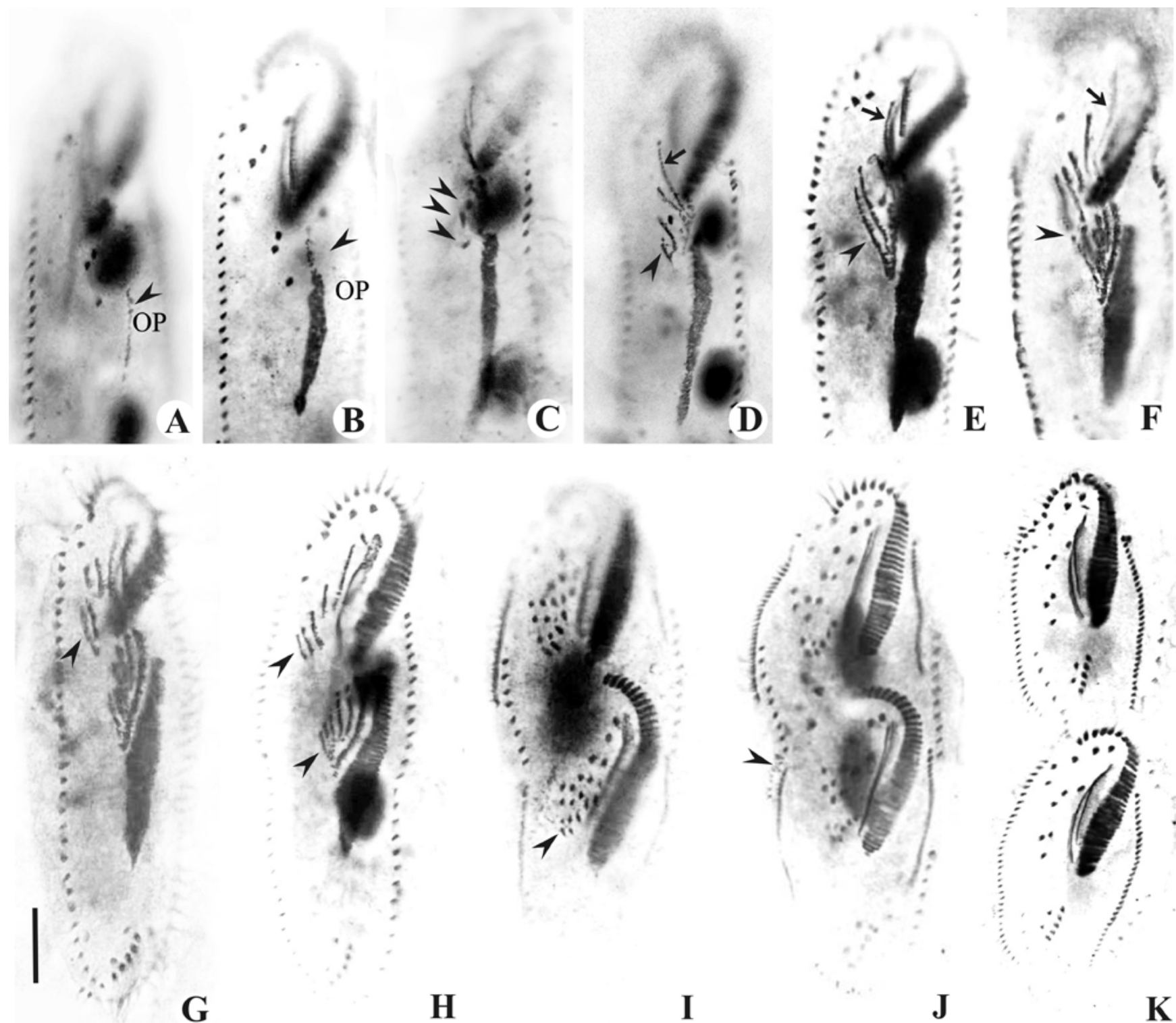

H

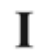

$\mathbf{J}$

K

Fig. 4. Photomicrographs showing morphogenetic stages on ventral surface of protargol impregnated cells of Aponotohymena isoaustralis n. sp. A, B - de novo origin of OP (arrowheads); C - POVC (arrowheads) not contributing to OP; $\mathbf{D}$ - dissagregation of V/4 and V/3 (arrowhead), movement of kinetosomes from OP to anterior region of the cell (arrow); $\mathbf{E}$ - elongation of two primary primordia (arrowhead), kinetosomes moved from OP to contribute in the formation of IIp (arrow); $\mathbf{F}$ - splitting of primary primordia (arrowhead), composite origin of IIp from OP and cirrus II/2 (arrow); $\mathbf{G}$ - primordia Vp and VIp (arrowhead) formed from splitting of primary primordia; $\mathbf{H}$ - full complement of 6 FVT primordia (arrowheads); I - differentiation of new FVT cirri (arrowhead); J - newly formed DMs on the ventral surface (arrowhead); $\mathbf{K}$ - cell in cytokinesis. OP - oral primordium. Scale bar: $20 \mu \mathrm{m}$.

or align between cirral rows or dorsal kineties whereas in $N$. apoaustralis, cortical granules are grouped around marginal cirri and dorsal kineties.

(4) SSU rDNA: The SSU rDNA nucleotide sequence of $A$. isoaustralis $\mathrm{n}$. sp. differs from that of A. australis $(2.92 \%)$ and $N$. apoaustralis $(4.24 \%)$ indicating that it is a distinct species.

\section{Comparison with the genus Notohymena}

According to Foissner (2016), the genus Aponotohymena is distinguishable from the genus Notohymena on the basis of difference in the number of caudal cirri. A detailed morphological, morphogenetic and molecular comparison suggests that there are several unique features of these two genera. 

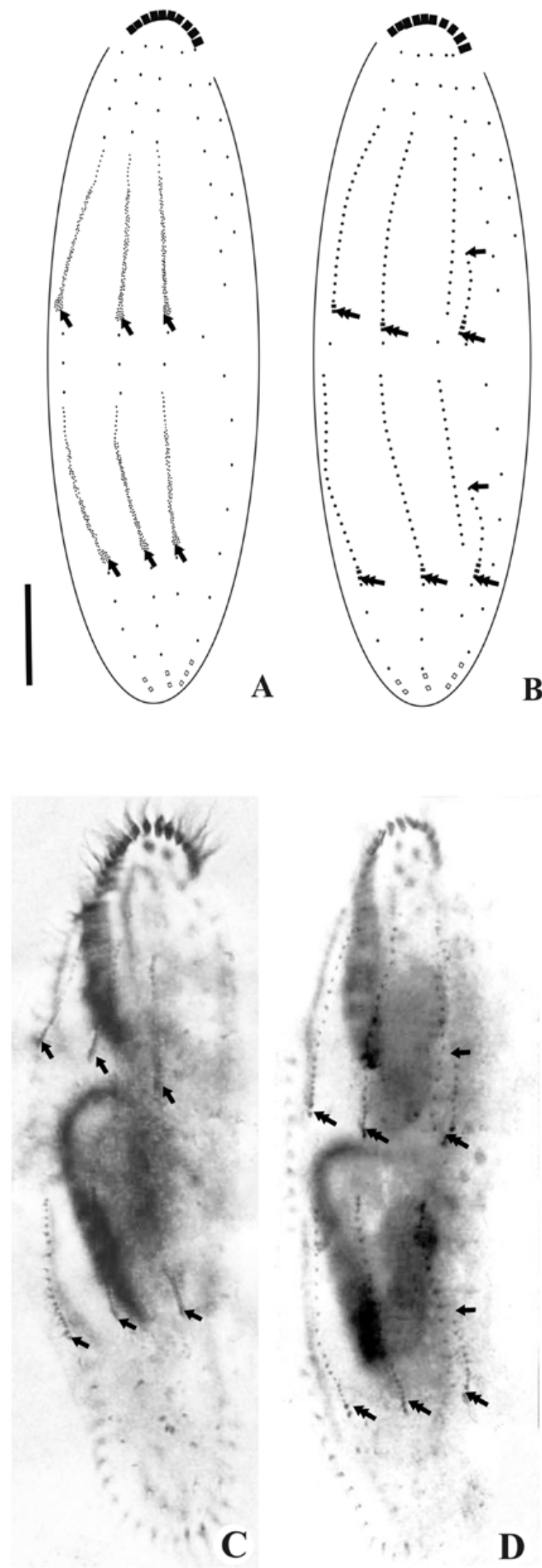

(1) Cortical granules: The cortical granules are yellowish green in colour in A. australis, A. isoaustralis $\mathrm{n}$. sp. and $N$. apoaustralis though the position varies (Voss 2008, Lv et al. 2013, Hu and Kusuoka 2015). On the contrary, colour of cortical granules varies in different species of Notohymena [N. rubescens - ruby coloured granules (Berger 1999); N. pampasica - colourless granules (Küppers et al. 2017); N. antarcticayellow to yellowish green granules (Berger 1999) and colourless granules in $N$. limus (Naqvi et al. 2016)].

(2) Number of caudal cirri: On the dorsal surface, supernumerary caudal cirri are formed by the posterior thickening at the end of $\mathrm{DK}_{1,2 \& 4}$ in A. australis, A. isoaustralis $\mathrm{n}$. sp. and $N$. apoaustralis which is in contrast to formation of three caudal cirri one each at the end of $\mathrm{DK}_{1,2 \& 4}$ of the other species of genus Notohymena (Table 3).

(3) Habitat: A. australis, A. isoaustralis n. sp. and $N$. apoaustralis are freshwater dwellers whereas the other species of Notohymena are from terrestrial habitat.

(4) Oral primordium (OP): OP arises as a thin long row of kinetosomes formed apokinetally between the post oral ventral cirrus $\mathrm{V} / 3$ and left marginal cirri (LMC) in A. australis, A. isoaustralis n. sp. and N. apoaustralis as also reported in some of the other oxytrichids (Foissner 1983; Foissner and Adam 1983a, b; Hemberger 1985; Wirnsberger et al. 1985, 1986; Ganner et al. 1986; Voss 1991a, b; Voss and Foissner 1996; Berger and Foissner 1997; Arora et al. 1999; Berger 1999, 2011; Chen et al. 2013; Li et al. 2014) whereas the formation of OP in other reported species of Notohymena seems to be species specific: $N$. rubescens $-\mathrm{OP}$ is generated close to uppermost transverse cirrus II/1, N. saprai - OP arises de novo close to IV/2, V/4, V/3 and $N$. limus - OP arises de novo close to $\mathrm{V} / 2$ and transverse cirri (Table 4).

(5) FVT primordia: The OP contributes to the formation of primordium IIp in A. isoaustralis n. sp. and thus IIp has a composite origin (2 different sources involvement of oral primordia and II/2) (Figs 3C, D, 4D-F) as also observed in some oxytrichids (Foissner

Fig. 5. Line diagrams and photomicrographs of Aponotohymena isoaustralis n. sp. showing morphogenetic stages on the dorsal surface after protargol impregnation. A, $\mathbf{C}$ - within row dorsal primordia formation for proter and opisthe with posterior thickening to form caudal cirri (arrows); B, D - unequal split of the third dorsal primordia (arrows); caudal cirri formed in $2+2+3$ pattern (double arrows) at the ends of $\mathrm{DK}_{1,2 \& 4}$ for proter and opisthe. Scale bar: $20 \mu \mathrm{m}$. 


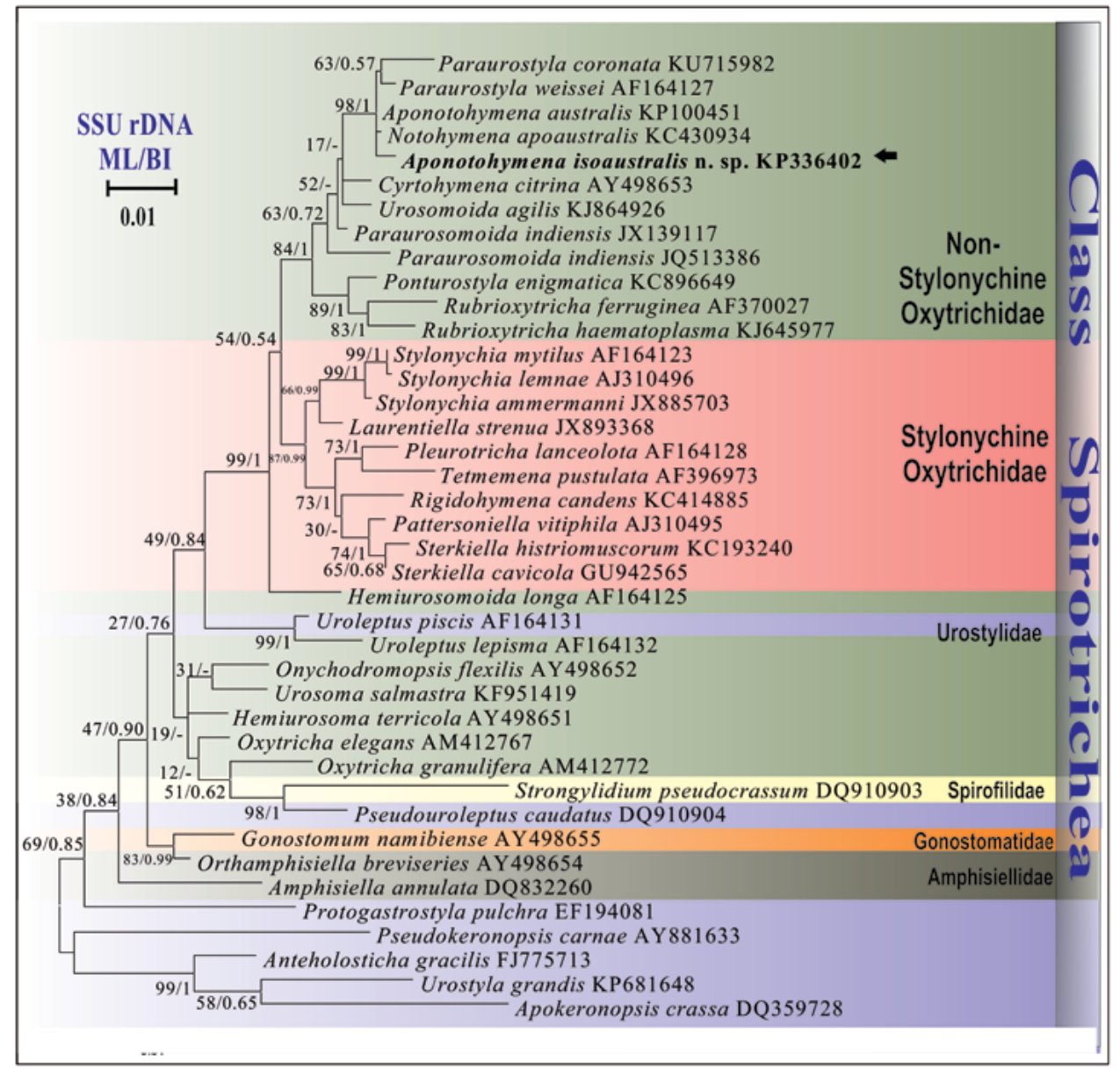

Fig. 6. Maximum likelihood (ML) phylogenetic tree based on SSU rDNA sequences showing the position of Aponotohymena isoaustralis n. sp. using GTR $+\mathrm{I}+\mathrm{G}$ as nucleotide substitution model. The new sequence from the present study is indicated by bold font (arrow). Numbers at nodes are bootstrap values from ML and the posterior probabilities from BI. Accession numbers are provided after species names. Clades representing different orders of the subclass stichotrichia are shaded. "-" at the nodes indicate disagreement between the two methods. The scale bar corresponds to 0.01 expected substitutions per site.

and Adam 1983b, Gupta et al. 2006). A detailed ontogenic development of IIp primordia is not available for $A$. australis and $N$. apoaustralis. In $N$. saprai IIp originates from cirrus II/2.

In $A$. isoaustralis n. sp. POVC (IV/2, V/4 and V/3), disaggregate independently to form streaks IVo, Vo and VIo, but do not seem to merge with the developing OP. This is in contrast with $N$. saprai where disaggregating POVC merge with the developing OP and may contribute to primordia formation of both proter and opisthe (Table 4).

(6) SSU rDNA: The molecular traits though cannot be discussed for the two genera (Aponotohymena and Notohymena) in detail as SSU rDNA or any other marker genes have not been sequenced so far in any of the reported species of the genus Notohymena. If the molecular marker genes of all species belonging to the genus Notohymena are characterized and described, a more robust and precise phylogeny of these genera can be obtained in future.

\section{Phylogenetic analyses}

On the basis of molecular analysis $A$. isoaustralis n. sp. is clustered with $N$. apoaustralis and A. australis within a clade which is also composed of Paraurostyla weissei and P. coronata (Fig. 6). The morphological and morphogenetic features that may explain close relationship of this clade is the presence of cortical granules, de novo origin of $\mathrm{OP}$ and supernumerary caudal cirri. Analysis of UM also leads to an assumption that curved UM may be autapomorphic trait for Notohymena and Aponotohymena which may have evolved from UM of 


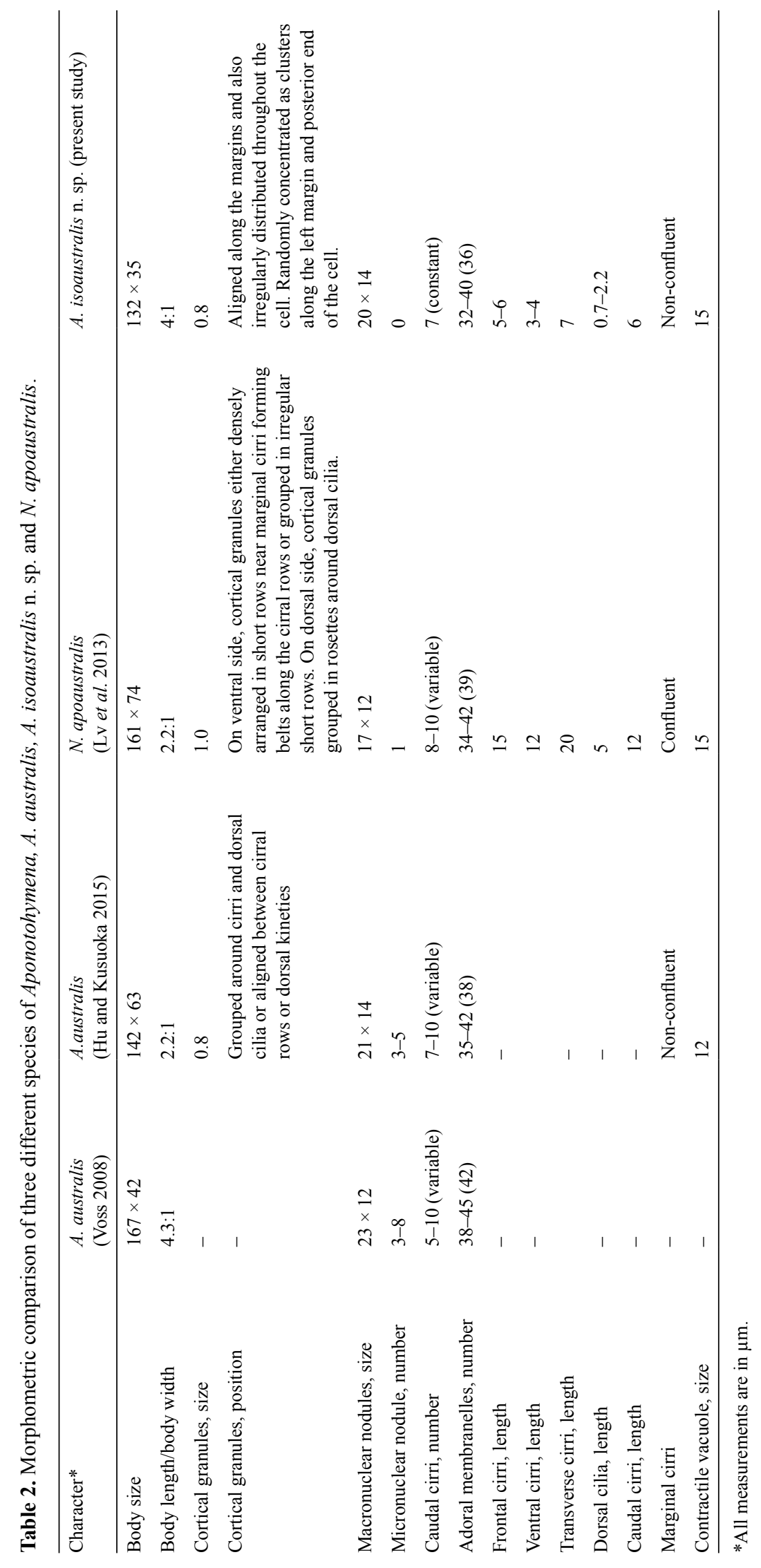


104 R. Gupta et al.

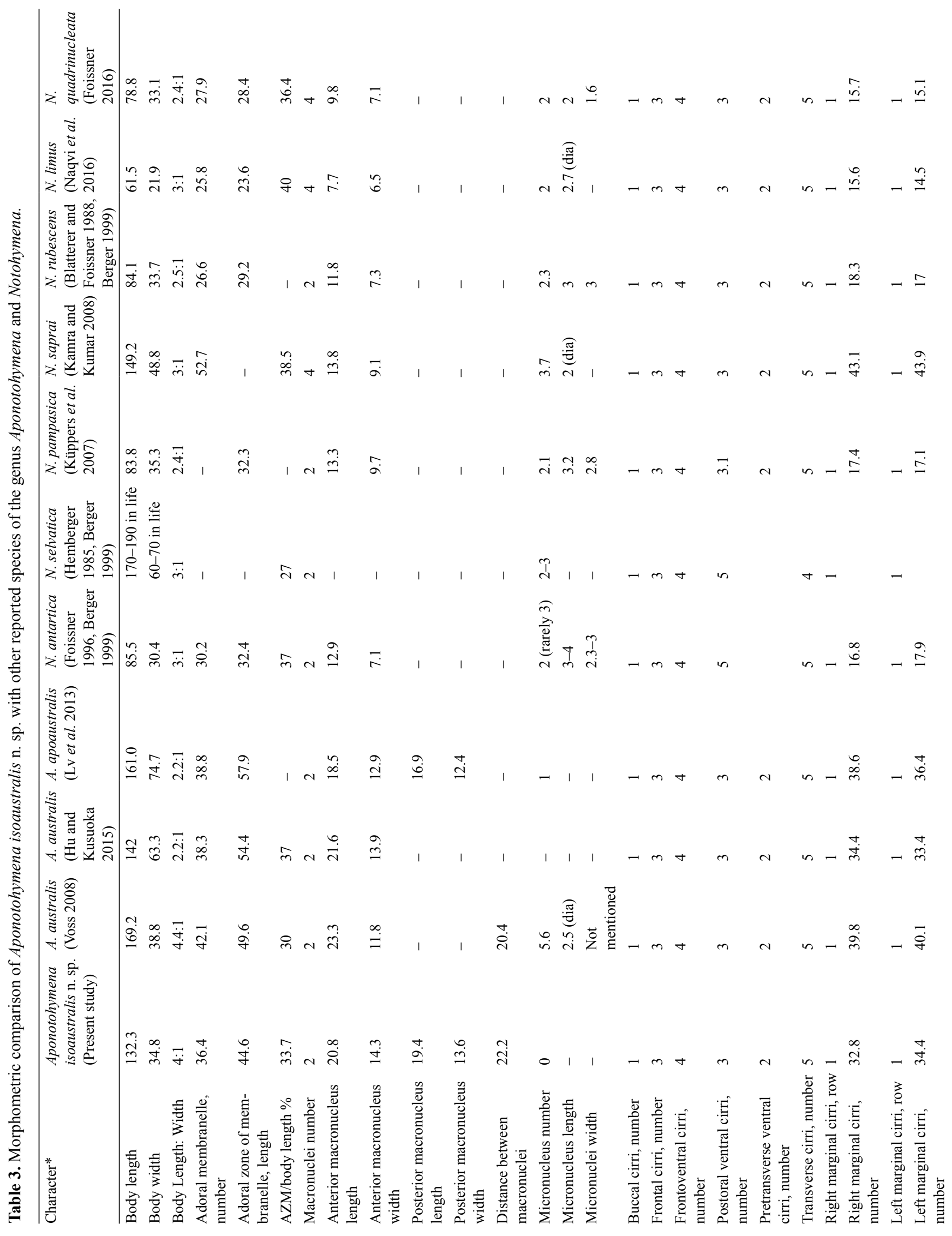


Description of Aponotohymena isoaustralis n. sp.

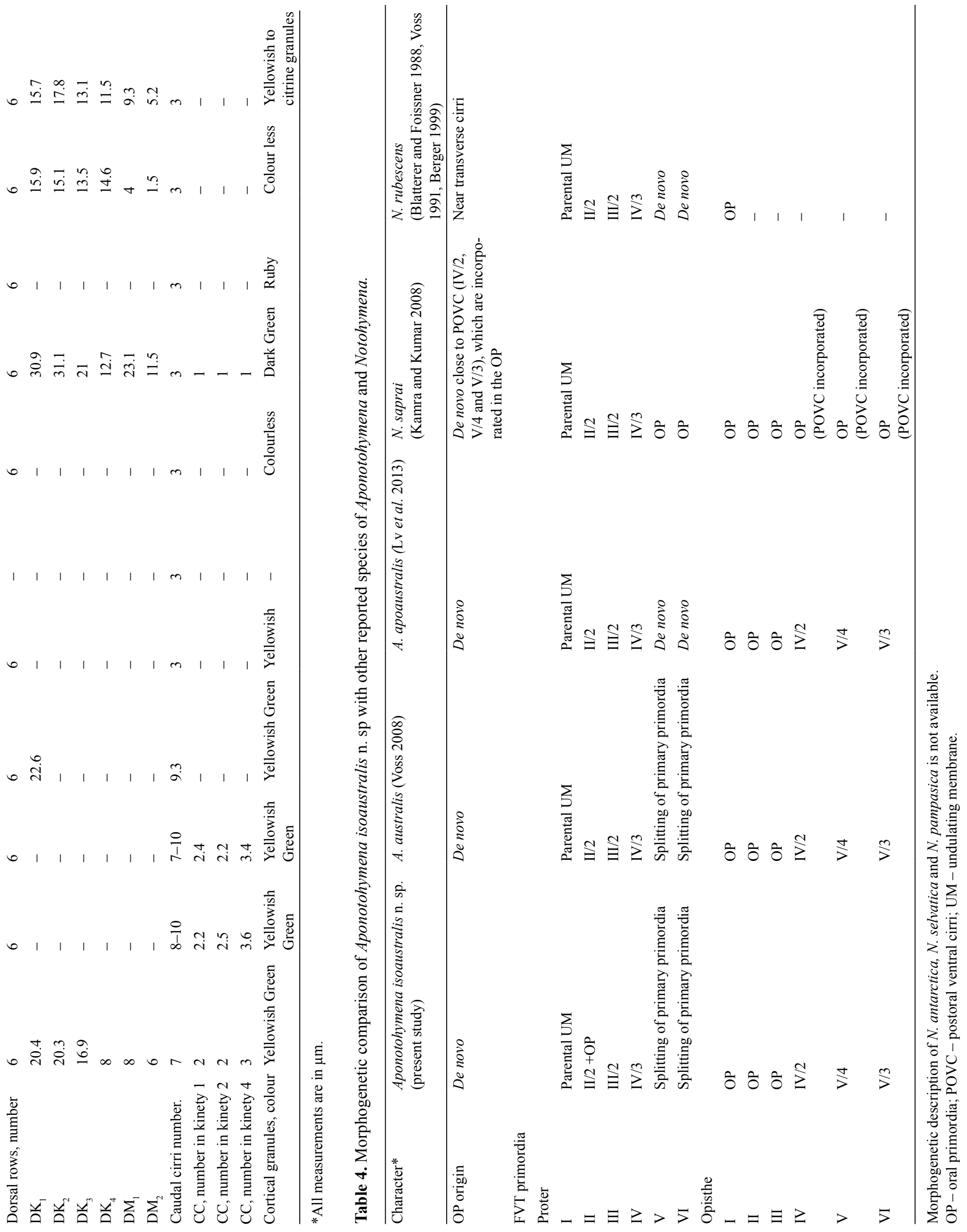


Paraurostyla pattern where endoral and paroral membranes are intersecting in the middle and rejoining at the distal side without forming hook at the distal end. Therefore, it is possible that the above-mentioned characters may be significant in the phylogeny and systematics of the family Oxytrichidae.

\section{Remarks}

A comparison of different species belonging to these two genera (Notohymena and Aponotohymena) suggests that $N$. apoaustralis should be included in the genus Aponotohymena and redesignated as A. apoaustralis nov. comb.

\section{Taxonomic summary}

Order Sporadotrichida Fauré-Fremiet, 1961

Family Oxytrichidae Ehrenberg, 1830

Diagnosis of Aponotohymena isoaustralis n. sp.: A freshwater flexible oxytrichid measuring about $148 \times$ $46 \mu \mathrm{m}$ in vivo, elongated body, yellowish green cortical granules about $0.8 \mu \mathrm{m}$ in diameter aligned along the margins and also irregularly distributed throughout the cell. They may also be randomly concentrated as clusters along the left margin and posterior end of the cell, adoral zone of membranelles about $34 \%$ of body length and is composed of 32-40 membranelles.18 FVT cirri with 3 frontal cirri, 4 frontoventral cirri, 1 buccal cirrus, 3 postoral ventral cirri, 2 pretransverse ventral cirri and 5 transverse cirri; one left and one right row of marginal cirri non confluent posteriorly; 4 dorsal kineties and 2 dorsomarginals; seven caudal cirri (constant) in $2+2+$ 3 pattern. 2 macronuclei and no micronucleus (amicronucleate). De novo oral primordium formation.

Type location: Freshwater samples from Sanjay lake, which is an artificial lake in Trilokpuri $\left(28^{\circ} 36^{\prime} 51^{\prime \prime} \mathrm{N}, 77^{\circ} 18^{\prime} 14^{\prime \prime} \mathrm{E}\right)$, East Delhi, India.

Type material: Protargol impregnated slide with holotype specimen (Fig. 1C, D) encircled in black ink is deposited in the Zoological Survey of India, Kolkata, India with accession number Pt. 3220.

Etymology: The species name isoaustralis refers to its similarity to $A$. australis.

Gene sequence: The SSU rDNA sequence of $A$. isoaustralis $\mathrm{n}$. sp. is deposited in GenBank with accession number KP336402.

Occurrence and ecology: Till date Aponotohymena isoaustralis $\mathrm{n}$. $\mathrm{sp}$. was recorded only at the type location. Although, three other freshwater lakes were sampled around Delhi, but the novel species has been exclusively found from samples of Sanjay Lake.
Acknowledgements. Authors appreciate the facilities provided by the Principal, Acharya Narendra Dev College, University of Delhi for carrying out the present study. The support extended by the Principal, Maitreyi College, University of Delhi is acknowledged. We are indebted to Professor G. R. Sapra for his constant encouragement and guidance. We thankfully acknowledge the support of UGC project (Delhi, India) F. No. 41-15/2012 (SR) and DST project (Delhi, India) SERB/F/1891/2012-13. The authors extend their sincere appreciation to the Deanship of Scientific Research at King Saud University-Saudi Arabia, Research Group number (RG-1436-242).

\section{REFERENCES}

Arora S., Gupta R., Kamra K., Sapra G. R. (1999) Characterization of Paraurostyla coronata sp. $\mathrm{n}$. including a comparative account of other members of the genus. Acta Protozool. 38: 133-144

Berger H., Foissner W. (1997) Cladistic relationships and generic characterization of oxytrichid hypotrichs (Protozoa, Ciliophora). Arch. Protistenk. 148: 125-155

Berger H. (1999) Monograph of Oxytrichidae (Ciliophora, Hypotrichia). Monographiae Biologicae. Springer 78: $1-1080$

Berger H. (2008) Monograph of Amphisiellidae and Trachelostylidae (Ciliophora, Hypotricha). Monographiae Biologicae. Springer 88: $1-737$

Berger H. (2011) Monograph of the Gonostomatidae and Kahliellidae (Ciliophora, Hypotricha) (Monographiae Biologicae, vol. 90). Springer 90: 1-742

Berger H., Foissner W. (1997) Cladistic relationships and generic characterization of oxytrichid hypotrichs (Protozoa, Ciliophora). Arch. Protistenkd. 148: 125-155

Blatterer H., Foissner W. (1988) Beitrag zur terricolen Ciliatenfauna (Protozoa: Ciliophora) Australiens. Stapfia. 17: 1-84

Borror A. C. (1972) Revision of the order Hypotrichida (Ciliophora, Protozoa). J. Protozool. 19: 1-23

Chapman-Andresen C. (1958) Pinocytosis of inorganic salts by Amoeba proteus (Chaos diffluens). C. R. Trav. Lab. Carlsberg. Chim. 31: 77-92

Chen X., Li L., Hu X., Shao C., Al-Farraj S. A., Al-Rasheid K. A. S. (2013) A morphogenetic description of Thigmokeronopsis stoecki Shao et al. 2008 (Ciliophora, Hypotricha) and a comparison with members of the family Pseudokeronopsidae. Acta Protozool. 52: 65-72

Chieco P., Derenzini M. (1999) The feulgen reaction 75 years on. Histochem. Cell. Biol. 111: 345-358

Doerder F. P. (2014) Abandoning sex: multiple origins of asexuality in the ciliate Tetrahymena. BMC evol. Biol. 14: 112

Ehrenberg C. G. (1830) Beiträge zur Kenntnniß der Organisation der Infusorien und ihrer geographischen Verbreitung, besonders in Sibirien. Abh. Preuss. Akad. Wiss., Phys. Math. K. I. 1-88

Fauré-Fremiet E. (1961) Remarques sur la morphologie comparée et la systématique des ciliata Hypotrichida. C. r. hebd. Séanc. Acad. Sci., Paris, 252: 3515-3519

Foissner W. (1983) Die Morphogenese von Urosoma macrostyla (Wrzésniowski 1870) (Ciliophora: Oxytrichidae). Arch. Protistenkd. 127: 413-428

Foissner W., Adam H. (1983a) Die Morphogenese von Urosomoida agiliformis Foissner 1982 (Ciliophora, Oxytrichidae). Zool. Anz. 211: 161-176 
Foissner W., Adam H. (1983b) Morphologie and morphogenese des Bodenciliaten Oxytricha granulifera sp. n. (Ciliophora, Oxytrichidae). Zool. Scr. 12: 1-11

Foissner W., O’ Donoghue P. J. (1990) Morphology and infraciliature of some freshwater ciliates (Protozoa: Ciliophora) from Western and South Australia. Invertebr. Taxon. 3: 661-696

Foissner W. (1996) Faunistics, taxonomy and ecology of moss and soil ciliates (Protozoa, Ciliophora) from Antarctica, with description of new species, including Pleuroplitoides smithi gen. n., sp. n. Acta Protozool. 35: 95-123

Foissner W., Stoeck T. (2011) Cotterillia bromelicola nov. gen., nov. spec., a gonostomatid ciliate (Ciliophora, Hypotricha) from tank bromeliads (Bromeliaceae) with de novo originating dorsal kineties. Eur. J. Protistol. 47: 29-50

Foissner W. (2016) Terristrial and semi-terristrial ciliates (Protozoa, Ciliophora) from Venezuela and Galápagos. Denisia 35: 1-912

Ganner B., Foissner W., Adam H. (1986) Morphogenetic and biometric comparison of four populations of Urosomoida agiliformis (Ciliophora, Hypotrichida). Annls Sci. Nat. (13e Series) 8: 199-207

Gupta R., Kamra K., Sapra G. R. (2006) Morphology and cell division of the oxytrichids Architricha indica nov. gen., nov. sp., and Histriculus histrio (Müller, 1773), Corliss, 1960 (Ciliophora, Hypotrichida). Eur. J. Protistol. 42: 29-48

Hemberger H. (1985) Neue Gattungen und Arten hypotricher Ciliaten. Arch. Protistenk. 130: 397-417

Hall T. A. (1999) BioEdit: a user friendly biological sequence alignment editor and analysis program for Windows 95/98/NT. Nucl. Acids Symp. Ser. 41: 95-98

Hu X., Kusuoka Y. (2015) Two oxytrichids from ancient lake Biwa, Japan, with notes on morphogenesis of Notohymena australis (Ciliophora, Sporadotrichida). Acta Protozool. 54: 107-122

Kamra K., Sapra G. R. (1990) Partial retention of parental ciliature during morphogenesis of the ciliate Coniculostomum monilata (Dragesco and Njiné 1971) Njiné 1978 (Oxytrichidae, Hypotrichida). Eur. J. Protistol. 25: 264-278

Kamra K., Kumar S. (2010) Notohymena saprai sp. nov, a new oxytrichid ciliate (Protozoa, Ciliophora) from the valley of flowers, a Himalayan bioreserve region; description and morphogenesis of the new species. Indian J. Microbiol. 50: 33-45

Küppers G. C., Claps M. C., Lopretto E. C. (2007) Description of Notohymena pampasica n. sp. (Ciliophora, Stichotrichia). Acta Protozool. 46: 221-227

Küppers G. C., Paiva T. da S., Borges B. do N., Harada M. L., Garraza G. G., Mataloni G. (2011) An Antartic hypotrichous ciliate, Parasterkiella thompsoni (Foissner) nov. gen., nov. comb., recorded in Argentinean peat-bogs: morphology, morphogenesis and molecular phylogeny. Eur. J. Protistol. 47: 103-123

Larkin M. A., Blackshields G., Brown N. P., Chenna R., McGettigan P. A., McWilliam H., Valentin F., Wallace I. M., Wilm A., Lopez R., Thompson J. D., Gibson T. J., Hiqqins D. G. (2007) Clustal W and Clustal X version 2.0. Bioinformatics 23: 29472948

Li F., Lv Z., Yi Z., Al-Farraj S. A., Al-Rasheid K. A. S., Shao C. (2014) Taxonomy and phylogeny of two species of the genus
Deviata (Protista, Ciliophora) from China,with description of a new soil form, Deviata parabacilliformis sp. nov. Int. J. Syst. Evol. Microbiol. 64: 3775-3785

Lv Z., Chen L., Chen L., Shao C., Miao M., Warren A. (2013) Morphogenesis and molecular phylogeny of a new freshwater ciliate, Notohymena apoaustralis n. sp. (Ciliophora: Oxytrichidae). J. Eukaryot. Microbiol. 60: 455-466

Medlin L., Elwood H. J., Stickel S., Sogin M. L. (1988) The characterization of enzymatically amplified eukaryotic 16 S-like rRNA- coding regions. Gene 71: 491-499

Naqvi I., Gupta R., Borgohain P., Sapra G. R. (2006) Morphology and morphogenesis of Rubrioxytricha indica $\mathrm{n}$. sp. (Ciliophora: Hypotrichida). Acta Protozool. 45: 53-64

Naqvi I., Gupta R., Makhija S., Toteja R., Abraham J. S., Somasundaram S., El-Serehy H. A. (2016) Morphology and morphogenesis of a new oxytrichid ciliate, Notohymena limus n. sp. (Ciliophora, Oxytrichidae) from Delhi, India. Saudi J. Biol. Sci. 23: 789-794

Prescott D. M. (1994) The DNA of ciliated protozoa. Microbiol. Rev. 58: 233-267

Tamura K., Peterson D., Peterson N., Stecher G., Nei M., Kumar S. (2011) MEGA5: Molecular evolutionary genetics analysis using maximum likelihood, evolutionary distance and maximum parsimony methods. Mol. Biol. Evol. 28: 2731-2739

Voss H. J. (1991a) Die Morphogenese von Cyrtohymena muscorum (Kahl, 1932) Foissner, 1989 (Ciliophora, Oxytrichidae). Arch. Protistenkd. 140: 67-81

Voss H. J. (1991b) Die Morphogenese von Notohymena rubescens Blatterer and Foissner 1988 (Ciliophora, Oxytrichidae). Arch. Protistenkd. 140: 219-236

Voss H. J., Foissner W. (1996) Divisional morphogenesis in Steinia sphagnicola (Ciliophora, Hypotrichida): a comparative light and scanning electron microscope study. Europ. J. Protistol. 32: $31-46$

Voss H. J. (2008) Divisional morphogenesis of Notohymena australis (Foissner and O' Donoghue, 1990) Berger 1999 (Ciliophora, Hypotrichida, Oxytrichidae). Denisia 23: 289-295

Wallengren H. (1900) ZurKenntnis der vergleichenden Morphologie der hypotrichen Infusorien. Bih. K. Svensk Vetensk Akad. Handl. 26: 1-31

Wilbert N. (1975) Eine verbesserte Technik der Protargol imprägnation für Ciliaten. Mikrokosmos 64: 171-179

Wirnsberger E., Foissner W., Adam H. (1985) Morphological, biometric and morphogenetic comparison of two closely related species, Stylonychia vorax and S. pustulata (Ciliophora: Oxytrichidae). J. Protozool. 32: 261-268

Wirnsberger E., Foissner W., Adam H. (1986) Biometric and morphogenetic comparison of the sibling species Stylonychia mytilus and S. lemnae, including a phylogenetic system for the oxytrichids (Ciliophora: Hypotrichida). Arch. Protistenkd. 132: 167 $-185$

Received on $31^{\text {st }}$ December, 2017; revised on $13^{\text {th }}$ June, 2017; accepted on $17^{\text {th }}$ July, 2017 